\title{
An Evaluation of the Lending Model of Commercial Banks in South Africa: The Case of Construction Industry
}

\author{
Lindy Yolande Mtsweni \\ University of South Africa, Janadel street, Midrand 1686 South Africa \\ Philip Serumaga-Zake \\ University of South Africa
}

Jan Kruger

University of South Africa

\begin{abstract}
The purpose of this study was to evaluate the commercial banks' lending model for small businesses in South Africa. The multiple case study design and purposive sampling were used to select six small businesses from a bank's database for the study. The qualitative data was categorised and analysed thematically. It was found that the lending criteria are based on the bank and client's long-term relationship, client's background, character, collateral, capital, capacity and affordability, that the lending model is helping to grow small businesses in the country. The commercial banks' lending policy should allow flexibility, among others, in terms of the minimum deposits and interest rates charged.
\end{abstract}

Keyword: Lending, commercial banks, small businesses, asset funding, South Africa

\section{INTRODUCTION}

The purpose of this study was to evaluate the commercial banks' lending model for small businesses in South Africa. In this study, a small business is defined as an SME or enterprise with one or more of the following characteristics: fewer than 200 employees, with annual turnover of less than R64 million, capital assets of less than R10 million, and direct managerial involvement by owner. The World Bank (2013) stated that, compared to larger firms, small businesses enhance competition, entrepreneurship, innovation, job creation and help to reduce poverty (Von Broembsen, Word \& Herrington, 2005). The SA commercial banks index (2013) reveals that the number of employees in the small businesses sector has risen by $6 \%$ year on year. However, small businesses are faced with many challenges such as legislation, finance assistance and training, which lead to limited exposure and ability to expand their businesses (Financial Mail 2013). Business operational issues and challenges such as compliance, regulations (Falkena, Bamber, Llewellyn \& Store, 2001) and policies, lack of sufficient capital and lending facilities are a major handicap to the development or growth of small businesses, especially in their early stages. Musara and Fatoki (2010) allege that the ability of start-up small businesses to grow depends strongly on their potential to have fixed assets and working capital for operations, the main components of Grunhagen and Mittelstaedt's (2002) model. Commercial banks evaluate the purpose of the required finance for each application and deliberate on the relevance thereof. The need of the lending facility should be legal, validated 
Mtsweni. L. Y., Zake, P. S., \& Kruger, J. (2020) An Evaluation of the Leading Model of Commercial Banks in South Africa: The Case of Construction Industry. Advances in Social Sciences Research Journal, 7(3) 403-415.

and in line with the applicant's core business interest. Deakins and Freel (2003) indicate that the business start-up process can be divided into a number of stages, namely, idea formulation, opportunity recognition, pre-start planning and preparation, entry and launch, and post-entry development. It is common knowledge that the overwhelming majority (about $95 \%$ of small businesses) rely on their personal resources, loans from friends and families or business partners to finance such businesses, which normally lead to failure in business (Temtime \& Pansiri, 2004; www.moneyweb.co.za).

Only about $5 \%$ of small businesses in the construction industry receive asset finance for business expansion from commercial banks, but the major challenge for commercial banks is the assessment of risk in a cost-effective manner. To this end, commercial banks developed an internal automated lending scoring scorecard to determine if a small business should be financed or not. A bank regulation is a form of government regulation, which subjects banks to certain requirements, restrictions and guidelines. This regulatory structure creates transparency between banking institutions and clients, among other things. Given the interconnectedness of the banking industry and the reliance that the national (and global) economy hold on banks, it is important for regulatory agencies to maintain control over the standardized practices of these institutions (www.globalbankreport.co.za). Commercial banks operate within a number of statutory requirements including the National lending Act, lending agreement Act and Usury Act which impose additional constraints to the lending of small business clients because certain requirements must be considered before the transaction is presented for consideration (Beck, 2007).

\section{The lending scoring model}

The use of the commercial banks' lending scoring system to assess the small business assets finance applications allows for consistent, standardized and transparent measures for lending risk (see Berger \& Frame, 2007; Brewer, 2007). The lending scoring also provides a quantitative estimate of a borrower's risk, allowing for differentiation in the loan approval process, loan conditions and pricing collection activities. According to commercial banks, the lending scorecard assesses the client's probability to default based on the client's history of payments and gives an indication of the profitability of such a transaction. This study was intended to evaluate the lending criteria of commercial banks for small businesses in South Africa.

\section{RESEARCH DESIGN AND METHODOLOGY}

A commercial bank in South Africa was randomly selected to be used in the study. The multiple case study design and qualitative methods approach (Yin, 2003; Baptiste, 2001; Lacity \& Janson, 1994) were then applied; and using the purposive sampling, six small businesses were selected in the construction industry whose owners or managers were interviewed. Data was also obtained from the bank's documents pertaining to loan applications. Of the six, three small businesses had their assets finance applications approved and three had theirs declined by the commercial bank. In addition, three senior members of management in the lending department of the commercial bank were interviewed. The data was categorised into patterns, trends and themes around which a narrative was written. The study was approved and obtained permission from the University of South Africa's Ethics Committee to be carried out. 


\section{Profiling of Cases}

\section{RESULTS}

This section shows the profile of small businesses that were used in the study (see Table 1).

Table 1: Profiles of cases

\begin{tabular}{|c|c|c|}
\hline & & \\
\hline & Approved applications & Declined applications \\
\hline Years in operation & $\begin{array}{l}10 \text { years } \\
14 \text { years } \\
6 \text { years }\end{array}$ & $\begin{array}{l}10 \text { years } \\
10 \text { years } \\
4 \text { years }\end{array}$ \\
\hline Industry & Construction & Construction \\
\hline $\begin{array}{l}\text { Ownership \& } \\
\text { management }\end{array}$ & $\begin{array}{l}3 \text { directors } \\
2 \text { directors } \\
1 \text { director }\end{array}$ & $\begin{array}{l}3 \text { directors } \\
1 \text { director } \\
1 \text { director }\end{array}$ \\
\hline Turnover & $\begin{array}{l}\text { R6 million } \\
\text { R10 million } \\
\text { R10 million }\end{array}$ & $\begin{array}{l}\text { R3 million } \\
\text { R5 million } \\
\text { R19 million }\end{array}$ \\
\hline Overdraft facility & $\begin{array}{l}\text { R300 } 000 \\
\text { R500 } 000 \\
\text { R600 } 000\end{array}$ & $\begin{array}{l}\text { R200 } 000 \\
\text { R0 } \\
\text { R250 } 000\end{array}$ \\
\hline Lending bureau & All cleared on ITC check & All cleared on ITC check \\
\hline Premises & $\begin{array}{l}2 \text { rented } \\
1 \text { owned }\end{array}$ & $\begin{array}{l}2 \text { rented } \\
1 \text { owned }\end{array}$ \\
\hline Surety & Yes & No \\
\hline Deposit & Minimum & Cash Flow impact \\
\hline
\end{tabular}

\section{Approved Firms Assets Finance Applications}

All approved applications belonged to applicants who had been in business for at least 6 years and family businesses with some members who had at least 20 years' experience in the construction industry, with engineering qualifications. They had a good lending history with good repayments on their accounts and no arrears. The typical relationship-based term loans were based on a business relationship built over years of lending, allowing for a substantial flexibility in loan terms. All the accounts that applicants had realised increased in their turnover from the previous year. One of the three small businesses with approved applications, however, had realised a loss of R300 000 due to high operational expenses on subcontracting experienced; a challenge which could have been eliminated if the business owned their assets and used their own skilled labourers to reduce high costs. This negativity was counteracted by the business being in good standing in terms of lending facility and had been profitable over the years; their balance sheet reflected a high equity ratio that placed comfort to the bank to grant an additional lending facility on acquiring assets that assisted the business to increase its turnover and profits. Two applicants were operating from rented business premises. The applications indicated that leveraged finance was required because the applicants demonstrated sustainable and predictable cash flows. 
Mtsweni. L. Y., Zake, P. S., \& Kruger, J. (2020) An Evaluation of the Leading Model of Commercial Banks in South Africa: The Case of Construction Industry. Advances in Social Sciences Research Journal, 7(3) 403-415.

Table 2 shows the results of the financial performance of the cases on firms' assets finance applications which were approved:

Table 2: Financial performance

\begin{tabular}{|l|l|l|}
\hline \multicolumn{1}{|c|}{ Case 1 } & \multicolumn{1}{c|}{ Case 2 } & \multicolumn{1}{c|}{ Case 3 } \\
\hline $\begin{array}{l}\text { The debt and turnover ratios } \\
\text { reflect that the business is } \\
\text { solvent. }\end{array}$ & $\begin{array}{l}\text { The debt and turnover ratios } \\
\text { reflect that the business is } \\
\text { solvent. }\end{array}$ & $\begin{array}{l}\text { The debt and turnover ratios } \\
\text { reflect that the business is } \\
\text { solvent. }\end{array}$ \\
$\begin{array}{l}\text { The business is profitable and } \\
\text { adding back the depreciation. } \\
\text { Affordability of the required } \\
\text { finance is not in doubt. }\end{array}$ & $\begin{array}{l}\text { The business is profitable and } \\
\text { adding back the depreciation. } \\
\text { Affordability of the required } \\
\text { finance is not in doubt. }\end{array}$ & $\begin{array}{l}\text { The business is profitable and } \\
\text { adding back the depreciation. } \\
\text { Affordability of the required } \\
\text { finance is not in doubt. }\end{array}$ \\
\hline
\end{tabular}

The results reveal that the banks required the businesses' audited latest financials and any other financial supporting documents (Balance Sheet, Income Statement, Cash Flow, Changes in Equity, Management Accounts and Assets and liabilities). All applicants had solvent businesses with notable profitably. A long-term relationship funding arrangement allowed the bank to offer concessionary rates to a borrower facing temporary lending problems, which the bank could later make up for when the firm returned to health (Brewer, 2007). Table 3 shows the clients' financial needs of the cases on firms' assets finance applications which were approved:

Table 3: The clients financial needs

\begin{tabular}{|l|l|l|}
\hline \multicolumn{1}{|c|}{ Case 1 } & \multicolumn{1}{|c|}{ Case 2 } & \multicolumn{1}{c|}{ Case 3 } \\
\hline $\begin{array}{l}\text { The company requires 2 } \\
\text { TLB's (Truck Loaders) as an } \\
\text { addition to the business due } \\
\text { to high demand and to reduce } \\
\text { maintenance costs and time } \\
\begin{array}{l}\text { as the other TLB's are old. } \\
\text { The new TLB's are more } \\
\text { reliable and more work can } \\
\text { be completed on time. }\end{array}\end{array}$ & $\begin{array}{l}\text { The company requires 2 } \\
\text { excavators TLB's as an addition to } \\
\text { the business due to an additional } \\
\text { work that is underway in two } \\
\text { different regions and contracts } \\
\text { are signed. }\end{array}$ & $\begin{array}{l}\text { The company requires 3 Vans } \\
\text { as an addition to the business } \\
\text { to deliver the mining supplies } \\
\text { of the secured contract. The } \\
\text { purchase of the 3 vans is } \\
\text { cheaper than renting as they } \\
\text { can be used on other sites as } \\
\text { well to save subcontract costs. }\end{array}$ \\
\hline
\end{tabular}

The results in the table show that all the banks managed to submit applications with clearly outlined needs and reasons for the assets as well as quotations showing the costs and discounts. The quotations were all from reputable suppliers or manufacturers as stipulated by the commercial bank. All applicants were applying for additional assets (one required TLBs, one excavator and the other required vans). Motivation for applicants was mainly for reducing operational costs. 


\section{Risk Mitigation and Repayment ability}

The banks require company risk and repayment ability mitigated through the company cash flows and to highlight the industry risk and expectations in the market (such as strikes). In addition, the system can determine the chances of a client defaulting on repayment of the loan and classify the risk category, for example, clients with a default grading of 1-15 is low risk whereas 15 and above is high risk to the bank (see Table 4). Table 4 shows the results of the risk mitigation and repayment ability of the cases on firms' assets finance applications which were approved:

Table 4: Companies risk mitigation and repayment ability

\begin{tabular}{|c|c|c|}
\hline Case 1 & Case 2 & Case 3 \\
\hline $\begin{array}{l}\text { The risk is minimal as the } \\
\text { company has a great proven } \\
\text { financial history. }\end{array}$ & $\begin{array}{l}\text { The risk is minimal as the } \\
\text { company has a great proven } \\
\text { financial history. }\end{array}$ & $\begin{array}{l}\text { The risk is minimal as the } \\
\text { company has a great proven } \\
\text { financial history. }\end{array}$ \\
\hline $\begin{array}{l}\text { Affordability is good, based on } \\
\text { the strength of the business and } \\
\text { the turnover. }\end{array}$ & $\begin{array}{l}\text { Affordability is good, based on } \\
\text { the strength of the business and } \\
\text { the turnover. }\end{array}$ & $\begin{array}{l}\text { Affordability is good, based on } \\
\text { the strength of the business; the } \\
\text { previous repayment amount is } \\
\text { similar to the previous amounts }\end{array}$ \\
\hline $\begin{array}{l}\text { The company is able to honour } \\
\text { its obligation. }\end{array}$ & $\begin{array}{l}\text { The company is able to honour } \\
\text { its obligation. }\end{array}$ & $\begin{array}{l}\text { on settled accounts and the } \\
\text { turnover reflects an increase } \\
\text { year on year }\end{array}$ \\
\hline $\begin{array}{l}\text { The main member (father) } \\
\text { owns another paving company, } \\
\text { only one director and this }\end{array}$ & $\begin{array}{l}\text { The main member is very } \\
\text { experienced. }\end{array}$ & $\begin{array}{l}\text { The company is able to honour } \\
\text { its obligation. }\end{array}$ \\
\hline $\begin{array}{l}\text { generates the secondary source } \\
\text { of income should the business } \\
\text { fail. }\end{array}$ & $\begin{array}{l}\text { The family is in the same } \\
\text { industry/business to support } \\
\text { each other. }\end{array}$ & $\begin{array}{l}\text { The main members are very } \\
\text { well known in the industry and } \\
\text { experienced. }\end{array}$ \\
\hline
\end{tabular}

An internal behavioural score system is a tool used by banks to check the client's affordability through the bank account conduct in terms of returns, access and how other existing loans are serviced and if the client is not over exposed or committed. Banks put in place internal exposure policies in place to guide them on maximum loans to be borrowed to clients, term on the loan, rate to be charged, when to expand, maintain and reduce a lending facility. The results on Table 8 above reveal that none of these applicants had any approved contracts for submission to motivate their application and strengthen the transaction, assuring that there is low risk. The collateral and security for each applicant was also analysed by the commercial bank.

\section{Collateral/Security}

The security can be signed by all members as per their ownership contribution to the business and in their own capacity or business. The purpose of security is to cover the banks' loan should the client fail to pay the debt. Table 5 shows the results of the commercial banks collateral requirements of the cases on firms' assets finance applications which were approved. 
Mtsweni. L. Y., Zake, P. S., \& Kruger, J. (2020) An Evaluation of the Leading Model of Commercial Banks in South Africa: The Case of Construction Industry. Advances in Social Sciences Research Journal, 7(3) 403-415.

Table 5: Collateral/Security

\begin{tabular}{|l|l|l|}
\hline \multicolumn{1}{|c|}{ Case 1 } & \multicolumn{1}{|c|}{ Case 2 } & \multicolumn{1}{c|}{ Case 3 } \\
\hline $\begin{array}{l}\text { All members are signing } \\
\text { unlimited surety as per their } \\
\text { ownership contribution to the } \\
\text { business for the financed } \\
\text { amount. }\end{array}$ & $\begin{array}{l}\text { The members are signing } \\
\text { unlimited surety as per their } \\
\text { ownership contribution to the } \\
\text { business for the financed } \\
\text { amount. }\end{array}$ & $\begin{array}{l}\text { All members are signing } \\
\text { unlimited surety as per their } \\
\text { ownership contribution to the } \\
\text { business for the financed } \\
\text { amount. }\end{array}$ \\
\hline
\end{tabular}

According to the table, all the applicants managed to cede security in the form of fixed assets, surety or loan guarantees to the value of the financed amount. One applicant submitted the article as surety for the loan application.

\section{Declined Firms Assets Finance Applications}

The background information in Table 6 reveals that all declined applications had been in business for about 10 years, owners held a bachelor's degree in commerce qualification with management skills but lacked construction skills, unlike the approved applicants. In terms of lending, declined applicants had a poor lending history with only fair repayment rates; one had arrears on existing accounts. Their lending standing negatively affected the commercial bank's business relationship with these clients which should have been built over the years of lending. All the applicants had realised some increases in their turnover from the previous year, however, they were not significant growth because of poor industry performance, and they were not able to sustain their existing debts. The net profit margins were low, and they had already exhausted all the lending facilities like term loans, overdrafts and lending cards. One applicant still had a high outstanding home loan.

All declined applicants failed to demonstrate sustainable and predictable cash flows including supporting documents like contracts to support their applications. In line with the Global Bank report (2015), a number of checks and balances are put in place by the financial industry to manage the risk associated with financing small business assets (Kauffman, 2005). The client's contribution to financing to minimise risk is known as deposit to the financed amount. Furthermore, the client doesn't have to bank with the same bank when borrowing money. Other banks simply require 6-month statements. Table 6 shows the results of the financial performance of the cases on firms' assets finance applications which were declined. 
Table 6: Financial performance

\begin{tabular}{|c|c|c|}
\hline Case 1 & Case 2 & Case 3 \\
\hline $\begin{array}{l}\text { The turnover and profit margin } \\
\text { ratios on the company reflected a } \\
\text { low increase margin of } 6 \% \text { in } \\
2012 \text { and only } 8 \% \text { in } 2013 \text {, net } \\
\text { profit after tax increased from } \\
\text { R781k to R1.4m. However, the } \\
\text { business liabilities and debt } \\
\text { gearing ratio were higher that the } \\
\text { industry norm of 5\%, it improved } \\
\text { from } 7.63 \% \text { in } 2012 \text { to } 6.13 \% \text { in } \\
2013 \text {. This simply means that the } \\
\text { business was indebted, and their } \\
\text { debts were reducing slower and } \\
\text { over a long term. } \\
\text { The business has unencumbered } \\
\text { assets which are already used as } \\
\text { collateral on the existing loans } \\
\text { The business is profitable, adding } \\
\text { back the depreciation and the } \\
\text { affordability of the required } \\
\text { finance is not in doubt }\end{array}$ & $\begin{array}{l}\text { The turnover of the client } \\
\text { showed a small increase of } 5 \% \\
\text { in } 2013 \text { and had a potential } \\
\text { growth of } 14 \% \text { should the bank } \\
\text { finance the asset and according } \\
\text { to the cash projection made. } \\
\text { The business offerings are still } \\
\text { not well known in the market } \\
\text { and only cater for clients that } \\
\text { are familiar with the concrete- } \\
\text { marbles flooring. } \\
\text { The business is solvent. } \\
\text { However, it reflects a debt } \\
\text { balance of R2.3m in the } \\
\text { business and client name and } \\
\text { slow growth to sustain the } \\
\text { current debt. } \\
\text { The business is profitable, } \\
\text { adding back the depreciation, } \\
\text { affordability was out of line } \\
\text { taking the probability of } \\
\text { interest rates, increase and } \\
\text { inflation versus the current } \\
\text { business growth rate into } \\
\text { consideration. }\end{array}$ & $\begin{array}{l}\text { The business turnover and } \\
\text { profit margin are reflecting a } \\
\text { low margin growth of } 5 \% \text { in } \\
2013 \text {. } \\
\text { The company has no existing } \\
\text { loans. However, during the } \\
\text { visit the business seemed slow } \\
\text { and surrounded by similar } \\
\text { businesses around the area. } \\
\text { The business is solvent and } \\
\text { profitable; adding back the } \\
\text { depreciation to substantiate } \\
\text { affordability puts strain on the } \\
\text { daily management of the } \\
\text { business. The bank account is } \\
\text { already reflecting a fair status } \\
\text { on its conduct. }\end{array}$ \\
\hline
\end{tabular}

According to the table, the declined applicants reflected a very low increase on turnover and net profit margins across. Furthermore, their existing debt ratios were highly geared which poses so much risk to the bank and there is a high probability of the applicants defaulting payments, leading into the article to be repossessed and the client losing other assets such as properties if ceded as collateral. Even the addition of depreciation to the net profit amounts, to increase affordability, did not significantly improve their chances of meeting the lending criteria of the bank. The other business had challenges in providing the banks with information required and presenting proof to convince the bank to accommodate their lending requests. The assessment of financial performance by banks is in line with the World Bank report (2015), the small business had cash flow difficulties which were significantly reduced in firms that kept a cash book, kept a record of debtors, practised active debtor management and controlled inventory. Implementing any of these practices was associated with a minimum of 33\% reduction in the probability of an exhausted overdraft and doing all four appeared to reduce this probability by as much as $61 \%$. Implementing these practices also significantly increased the probability that a firm would succeed in an application for term loan or assets finance. The GEM (2003) report concluded that a policy priority in SA was implementing programmes, including mentorship and 
Mtsweni. L. Y., Zake, P. S., \& Kruger, J. (2020) An Evaluation of the Leading Model of Commercial Banks in South Africa: The Case of Construction Industry. Advances in Social Sciences Research Journal, 7(3) 403-415.

training programmes that addressed the apparent financial management weaknesses in many Small Businesses (Orford et al., 2003).

A 2007 study by the World Bank reveals that barriers to accessing loans in South Africa's banking institutions were very low. South African financial institutions take an average of 4.13 days to process a Small Business loan as compared to an international average of 11.03 days. It is a fact that a small Business lending application takes around two times more days than other corporate business loans. This is probably owing to the lack of quality information being provided on the part of applicants. The commercial bank also complies with the relevant regulations in SA. Some of these include financial performance. The purpose of the financial performance of the business is to determine any changes such as selling of assets, financial strategy, financial challenges faced by the business and the financial strength of the business. The banks have ratios in place to assist in reviewing the leverage of the business, normally measured by the debt-asset ratio, business profitability and volatility of income, existing and projected cash flow, financial ratios including profitability ratios, liquidity ratios, efficiency ratios and debt ratios with interest cover being one of the most important (Total Sales, Loan Size as \% of Sales, Total Debt/Equity, Current Ratio, Inventory Turnover, Interest Coverage, Debt Coverage Ratio).

It is important for the bank to analyse the following, through the financial statements:

- Capital Structure - The net worth of the business through the assets versus liabilities, their gearing ratios which determine who take the most risk the bank or the client through the deposit and if there are hidden reserves or deficit.

- Operating performance - An analysis of profit ratios, trend of revenue increase or decline and the key drivers.

- Liquidity - The operating cash flow of the business, current and quick ratios to establish how quick the client can turn their stock into cash, debtor, lending and stock ratios and their spread in terms of how quick the client collects from their debtors and cash flow statement

- Debt service - How well does the client service their existing debts, interest/debt cover ratios, amount and type?

- Management accounts - The bank normally assess the performance of the business against the cash flow projections over 6 to 12 months period.

Table 7 shows the results of the clients' financial needs of the cases on firms' assets finance applications which were declined: 
Table 7: The clients financial needs

\begin{tabular}{|l|l|l|}
\hline \multicolumn{1}{|c|}{ Case 1 } & \multicolumn{1}{c|}{ Case 2 } & \multicolumn{1}{c|}{ Case 3 } \\
\hline $\begin{array}{l}\text { The company requires 2 } \\
\text { trucks as an addition on the } \\
\text { business to accommodate } \\
\text { the requirement of the new } \\
\begin{array}{l}\text { constructions contract to } \\
\text { build an office park. A new } \\
\text { truck is more reliable, and } \\
\text { more work will be } \\
\text { completed on time. }\end{array}\end{array}$ & $\begin{array}{l}\text { machine as an additional article to } \\
\text { generate more income and expand the } \\
\text { business. The need for the new machine } \\
\text { is to modernise and speed up } \\
\text { operations. This new machine allows } \\
\text { the client to take on larger jobs and } \\
\text { perform the same task in half the time. } \\
\text { At present the client has been awarded } \\
\text { a major contract for June (2014) ending } \\
\text { in November (2014) valued at R7.8m } \\
\text { but the contract is not signed. }\end{array}$ & $\begin{array}{l}\text { The company requires } 2 \\
\text { tippers trucks as an } \\
\text { addition on the business } \\
\text { to deliver the sand and } \\
\text { concretes. The need for } \\
\text { the trucks is to expand the } \\
\text { business to grow their } \\
\text { clientele and be able to } \\
\text { deliver clients orders on } \\
\text { time and quicker. }\end{array}$ \\
\end{tabular}

The results reflected in the table were similar with those of the approved applications mainly for business expansion and to increase capacity. The major hurdle for declined applicants was along the performance of the business which would reduce their deposit amounts. These findings are in relation to the Banking Association of South Africa (2013) which indicates that the South African population consists predominantly of lower income earners who had limited or no access to regular lending channels. Coming from poorer backgrounds, the lack of finance for these declined applications worsen their ability to access funding which would expand their business.

Table 8 shows the results of the risk mitigation and repayment ability of the cases on firms' assets finance applications which were declined:

Table 8: Companies risk mitigation and repayment ability

\begin{tabular}{|c|c|c|}
\hline Case 1 & Case 2 & Case 3 \\
\hline $\begin{array}{l}\text { The risk is minimal as the } \\
\text { company has a great } \\
\text { proven financial history. }\end{array}$ & $\begin{array}{l}\text { The risk is minimal as the } \\
\text { company has a great proven } \\
\text { financial history. }\end{array}$ & $\begin{array}{l}\text { The risk is minimal as the } \\
\text { company has a great proven } \\
\text { financial history. }\end{array}$ \\
\hline $\begin{array}{l}\text { Affordability is good, based } \\
\text { on the strength of the } \\
\text { business and the turnover. } \\
\text { The company is able to } \\
\text { honour its obligation. }\end{array}$ & $\begin{array}{l}\text { Affordability is good, based on } \\
\text { the strength of the business } \\
\text { and the turnover. } \\
\text { The company will be able to } \\
\text { honour its obligation. }\end{array}$ & $\begin{array}{l}\text { Affordability is good, based on } \\
\text { the strength of the business, the } \\
\text { previous repayment amount is } \\
\text { similar to the previous amounts } \\
\text { on settled accounts and the } \\
\text { turnover reflect an increase year }\end{array}$ \\
\hline $\begin{array}{l}\text { The members own another } \\
\text { distribution company, only } \\
\text { one director, and this } \\
\text { generate the secondary } \\
\text { source of income should } \\
\text { the business fail. }\end{array}$ & $\begin{array}{l}\text { The client to sign the } \\
\text { unlimited surety and based on } \\
\text { the new contracts received, } \\
\text { the business is able to afford } \\
\text { this new instalment payment, } \\
\text { reflected on the cash flow } \\
\text { projection. }\end{array}$ & $\begin{array}{l}\text { on year. } \\
\text { The company is able to honour } \\
\text { its obligation. } \\
\text { The main member is very well } \\
\text { known in the industry and } \\
\text { experienced. }\end{array}$ \\
\hline
\end{tabular}


Mtsweni. L. Y., Zake, P. S., \& Kruger, J. (2020) An Evaluation of the Leading Model of Commercial Banks in South Africa: The Case of Construction Industry. Advances in Social Sciences Research Journal, 7(3) 403-415.

According to the table, the declined applicants had a risk of financial strain on their cash flow should the applications be approved based on their lending history, financial performance and low deposit amounts. Table 9 shows the results of the commercial banks collateral requirements of the cases on firms' assets finance applications which were declined.

Table 9: Collateral/Security

\begin{tabular}{|c|c|c|}
\hline Case 1 & Case 2 & Case 3 \\
\hline $\begin{array}{l}\text { The assets to be financed were to be } \\
\text { ceded as collateral to the bank. } \\
\text { All members are signing unlimited } \\
\text { surety as per their ownership } \\
\text { contribution to the business for the } \\
\text { financed amount. However, they } \\
\text { already had existing loans in the } \\
\text { business name and in their own } \\
\text { capacity and their fixed assets and } \\
\text { investments were already ceded. This } \\
\text { poses a high risk to the bank should } \\
\text { they default payment or failure in } \\
\text { their business. }\end{array}$ & $\begin{array}{l}\text { The assets to be financed were } \\
\text { to be ceded as collateral to the } \\
\text { bank. } \\
\text { The member was signing } \\
\text { unlimited surety to the business } \\
\text { for the financed amount. } \\
\text { The client is willing to cede } \\
\text { R1million of his own property to } \\
\text { cover a portion of the finance as } \\
\text { the client property is only } \\
\text { bonded for R1.25million and the } \\
\text { property is worth close to R3 } \\
\text { million. All other fixed assets } \\
\text { were already ceded to the banks } \\
\text { for other finance. }\end{array}$ & $\begin{array}{l}\text { The assets to be financed } \\
\text { were to be ceded as } \\
\text { collateral to the bank. } \\
\text { The member was signing } \\
\text { unlimited surety of his } \\
\text { R100k investment to the } \\
\text { business for the financed } \\
\text { amount. } \\
\text { The client's proposed } \\
\text { investment cover was } \\
\text { very low against the } \\
\text { finance amount of R1m } \\
\text { and he had no property in } \\
\text { his name as the property } \\
\text { was sold and profit was } \\
\text { used as capital to start the } \\
\text { business. }\end{array}$ \\
\hline
\end{tabular}

The table reflects that the clients had already signed surety on other existing loans and the new surety would put the commercial bank at risk should the client default payment because the applicants were overexposed by signing all business assets. The banks usually consider the financed assets as the collateral. However, an additional security is required on specialised assets as the bank can face a risk of failing to sell the assets or at no value. The collateral requirements on finance within the banks are in line with a study conducted by Mail \& Guardian (2013), that Small Businesses in South Africa are meant to create jobs and grow the economy but a highly concentrated economy, a poorly skilled workforce, stringent red tape, a high failure rate and a lack of an entrepreneurship culture are all affecting the sector's performance. Furthermore, entrepreneurs across various sectors are experiencing challenges in accessing financial assistance to start or grow their business through financial institutions (Maas \& Herrington, 2008; Herrington, Kew \& Kew, 2008; 2010). This is due to rigid lending criteria and not meeting set requirements, including collateral securities (FinScope Small Business Survey, 2010). Hussian et al. (2006), state that when the cost of survival or growth in firms exceed the availability of financial resources owned or controlled by owners, they become dependent on the availability of external sources of finance. 


\section{Compliance on Approved and Declined Applications}

Compliance is an important aspect of any bank as most of these legislations are proposed and implemented by the government to protect both clients and the banks against reckless lending, money laundering, knowing your customers (FICA), FAIS and so forth. The banks have put monitoring systems in place to ensure that they comply with the requirements and don't face fines or lose their licence. All applicants were compliant with all the required stipulations for FAIS, FICA, CASA, BEE and NCA. The lending team from the commercial bank summarises their findings with recommendations on the application sheet. The recommendation on the lending application summarises the entire motivation.

The following are some of the overall commercial banks' recommendations on the approved and declined cases on firms' assets finance applications:

- Good bank client since 2008

- Well conducted account with no returns and access.

- Good increase on turnover.

- Existing assets finance client, good track account paid well.

- $20 \%$ deposit, 48 months, VAT back paid month $2-7$.

- Good bank client since 2005.

- Well conducted account with no returns and access.

- Good increase on turnover and potential growth of $14 \%$ year on year expected.

- Existing assets finance client, good track account paid well.

- Good bank client since 2001.

- Well conducted account with no returns and access.

- $20 \%$ deposit, 60 months, no VAT back required.

Based on the results of the table, a decision is finally made based on the recommendations and in line with the banks' lending policies. The decision has two outcomes either a decline or an approval.

\section{Approved applicants}

It was clear that all approved applicants had good track records, with accounts that were not overdrawn, previous good payment profiles, increasing turnover and profits, financially sound from the previous years, high deposits were paid to secure the lending and thus showed commitment to the banks. These applicants were able to carry the Vat back portion upfront as banks only finance the capital amounts, they demonstrated less risk to the bank in terms of affordability and all company members had existing assets to serve as surety. Furthermore, the approved applicants were very experienced in this industry and were able to present additional documentations such as signed contracts, cash flow projection over a year to support the lending. Most companies were family businesses, and some had strong support from family members in the similar business.

\section{Declined applicants}

On the declined cases, the clients could not meet the minimum deposits criteria. Some of the applicants were overexposed to qualify for additional finance and had already ceded their assets 
Mtsweni. L. Y., Zake, P. S., \& Kruger, J. (2020) An Evaluation of the Leading Model of Commercial Banks in South Africa: The Case of Construction Industry. Advances in Social Sciences Research Journal, 7(3) 403-415.

to the existing outstanding loans. There was only one small business applicant director's structure made up of family members while others were wholly owned by one member with limited experience in the industry and minimal skills and qualifications. The declined applicants' financial status in terms of their turnover and profit margin growth was low and unstable posing a risk to the banks decision of granting additional finance. In addition, the declined applicants failed to present supporting information such as signed contracts, cash flow projections unlike the approved applicants to strengthen the banks decision in approving their finance requests. The analysis outcome can be related to Malik Fal, the managing director of the Omidyar Network Africa, which promotes and funds high-impact entrepreneurs (Fal, 2013). Omidyar's Accelerating Entrepreneurship in Africa survey released in April (2014) reveals that South Africa's small businesses are held back by four main challenges:

- Business regulations

- Access to a skilled workforce or business skills

- Access to finance and lack of collateral

- Poor quality of financial statements and business plans.

\section{DISCUSSION, CONCLUSION AND RECOMMENDATIONS}

This paper provides recommendations and modifications necessary to be made on the assets finance lending criteria to grow the small businesses in the construction industry. Based on the lending criteria, particularly on background checks, the commercial banks may have waived some of the basic screening questions. To simplify the financial requirements, the commercial bank relies on the available information, figures and statistics under their custody. The commercial bank raised a concern on poor quality of lending applications and clients not supplying sufficient required documentation or additional information to mitigate the risk and support the applications. The commercial bank may consider improving their current lending system and allow Small Businesses to have an option of applying for lending online. This would reduce the amount of poor-quality applications submitted. The banks should also have controls in place not to proceed with the application until all supporting documents are supplied. The lodgement on the overall complaints received by the commercial banks, revealed that customers complain about the high pricing on interest rates, short term of finance, high upfront deposits and service fees charged by the commercial banks on repeat buyers and assets to be used to grow the business. Commercial banks may consider reviewing their pricing and finance policy. They should consider pricing according to the period of their relationship with the client. They may review the finance policy on collateral requirements as the financed assets are automatically ceded to the bank, which should be enough to minimise the banks" risk.

\section{RECOMMENDATIONS}

The commercial banks' lending policy should allow flexibility in terms of the maximum finance terms, minimum deposits and interest rates charged. For example, where new assets are financed the commercial banks should allow the finance term to be more than 4 years, to stretch the repayment amounts and ease the high instalment burden. Programmes for small businesses may have to be advised to do basic business administration, and these should be carried out together with other stakeholders such as SIDA, IDT or other government entities. 


\section{References}

1. Baptiste, I. 2001. Qualitative Data Analysis: Common Phases, Strategic Differences. Forum Qualitative Sozialforschung / Forum: Qualitative Social Research: 2(3).

2. Beck, T. 2007. Financing Constraints of SMEs in Developing Countries: Evidence, Determinants and Solutions. Available from www.tilburguniversity.edu/webwijs/files/.../beck/.../financingconstraints...., accessed on 23/05/2014.

3. Berger, A.N \& Frame, W.S. 2007. Small business lending scoring and lending availability, Journal of Small Business Management, Vol. 45, No. 1, 5-22.

4. Brewer, E. 2007. On lending to small firms. Journal of Small Business Management, Vol. 45, No. 1, 42-46.

5. Deakins D \& Freel M. 2003. Entrepreneurship and small firms. 4th ed. Berkshire: McGraw-Hill.

6. Fal, M. 2013. Ventureburn talks entrepreneurship with Omidyar Network Africa's Malik Fal. Available from ventureburn.com/2013/.../ventureburn-talks-entrepreneurship-with-omid..., accessed on 4/8/2014.

7. Falkena, H.B., Bamber, R., Llewellyn, D. and Store, T. 2001. Financial Regulation in South Africa, Published by SA Financial Sector Forum, Second Edition (March).

8. Herrington, M., Kew, J. \& Kew, P. 2008 Global Entrepreneurship Monitor. South Africa Executive Report. Graduate School of Business, University of Cape Town. Available from: www.gemconsortium.org (accessed 16/07/2014).

9. Herrington, M., Kew, J. \& Kew, P. 2010. South Africa 2009 Report - Tracking entrepreneurship in South Africa: A GEM Perspective. Graduate School of Business, University of Cape Town. Available from: www.gemconsortium.org (accessed 16/07/2014).

10. Kauffman, C. (2005). Financing SMEs in Africa. Policy Insights No. 7, African Economic Outlook 2004/2005, ADB and OECD. www.oecd.org/dev/aeo

11. Lacity, M.C. \& Janson, M.A. 1994. Understanding qualitative data: a framework of text analysis methods. Journal of Management Information Systems, 11(2):137-155.

12. Maas, G. \& Herrington, M. 2008. Global Entrepreneurship Monitor South African Report 2007. Cape Town: University of Cape Town Graduate School of Business.

13. Musara, M., and Fatoki, O. 2010. Has technological innovations resulted in increased efficiency and cost savings for banks' customers? African Journal of Business Management, 4(9): 1813- 1821

14. Temtime, Z.T. and Pansiri, J. (2004), Small business critical success/failure factors in developing economies: some evidence from Botswana, American Journal of Applied Sciences, Vol. 1 No. 1, pp. 18-25.

15. Von Broembsen, SL., Word, E. \& Herrington, M. 2005. Global Entrepreneurship amonitor: South African Report. [Online.] Available from:

16. http://www3.babson.edu/Newsroom/Releases/Globalgem11206release.cfm-38. Accessed on 04/09/2014.

17. Yin, R. K. (2003). Case study research: Design and methods (3rd ed.). Thousand Oaks, CA:Sage.

\section{Sources}

World Bank (2013)

Financial Mail, 2013

\section{Web Links}

http://www.moneyweb.co.za

http://www.globalbankreport.co.za 